ment of the dance series held in honour of some person or to celebrate some local occasion. Clearly additional food must be forthcoming for such events. It could not be bought with cash in earlier times : it had to be produced, and this encouraged and increased agricultural activity. But with the decrease in dancing has come a decrease in agricultural production. At the same time the villagers' assessment of the value of cash appears to be immature. They are prone to spend it on social requirements, such as ceremonial payments, to the detriment of their nutritional needs ; and the Administration's effort to improve their health conditions has met with a resistance backed by generations of conservatism towards change.

These few specimens from the descriptions in the survey can be summarized in a sentence : where the people have assimilated an element of Western culture they have not assimilated also its associated characteristics and institutions (F. C. Bartlett, "Psychology and Primitive Culture," Cambridge, 1923). This accounts to some extent for their present pattern of culture being made up of indigenous and European elements side by side. Where this close association of cultures exists it is to be expected that the entity of the less dominant one will suffer. That has hap. pened in Hanuabada, and its people are not now enjoying the best of either.

But there are some signs of a brighter future. They seem to realize that a complete acceptance of Western custom is beyond competition. This may be a good feature in their mental attitude if it does not altogether stifle their ambition. They have shown themselves competent to administer co-operative societies on modern lines; and administrative ability-and integrity-should stand them in good stead for any job requiring responsibility. Despite their comparatively low income they do, in fact, save money for specific purposes, even though the original incentive to save may be conveniently overlooked if an unexpected call for money arises for some quite different purpose. Un the moral side, the people appear to have been attracted by the Scout movement and this, apart from its other intrinsic merits, has contributed towards good race relations with Europeans.

From an anthropological point of view the amount of detail that Prof. Belshaw has given is not consistent with its importance under the various headings of his subject. More could profitably have been included on women's customs (pp. $162 \mathrm{ff}$.) - very rightly collected by his wife--since absence of such knowledge hampers any administration in its ability to guide their advancement compared with the guidance for menfolk, of whose customs a far greater knowledge is available; and the women's position in a society at any given time is often a criterion of its development towards an enhanced level of living. Another criterion of welfare in its widest sense is the rate of infant mortality over a period. The figure is high for the year when the survey was done, but it would have been helpful to know the trend of the infant mortality-rate. It is a pity that more material for the survey was not obtained in the vernacular and that so much reliance was-apparently-placed on the opinions of the three Papuan officials "without whose services the research could not have been completed in its present form" (p. ix). Comment by Hanuabadans on their own welfare as they see it now and in the future would have added to the value of the survey. If Prof. Belshaw had had longer experience in the British Colonial Service he would probably have appreciated the substantial difficulties of the
Administration in Papua in its endeavours to improve the lot of the Hanuabadans. His advice to the Administration and criticism of its decisions might have been more appropriately confined wholly to a final chapter instead of being scattered throughout the book. The sixteen photographs could have been clearer and more illustrative of the text.

"The Great Village" is the first account of its kind to deal with this part of the Pacific. Coming from a trained anthropologist, the Administration will no doubt welcome it as a painstaking and independent survey of modern conditions, and it is a book that should well repay close study by all whose interests take them to work in Papua, particularly those with administrative interests. It has the added advantage of being a factual, first-hand record of the "welfare anthropology' of the Hanuabadans at a time when they are constantly subject to changes imposed from outside.

G. K. Rотн

\section{GALILEO AND THE HOLY OFFICE}

\section{The Crime of Galileo}

By Prof. Giorgio de Santillana. Pp. xvi $+339+8$ plates. (London: William Heinemann, Ltd., 1958.) 30s. net.

CHE literature on the process of the Holy Office against Galileo is enriched in this book with a most noteworthy contribution. Prof. G. de Santillana, a scholar who has earned an international reputation by his books and articles on the history of science, has reconsidered the whole much-debated issue, making use of all the well-known documents and of numerous little-known ones, which are brought here into the discussion for the first time. By studying all these with the utmost care and acumen he has succeeded in throwing fresh light on several dark places and in solving various enigmas in the course of the affair. He will be the first to acknowledge that a great number of questions may still be asked which are probably destined to remain unanswered for ever. This, however, does not detract in any way from the great merit of having presented us with a wholly original view on one of the most important and interesting conflicts that has ever arisen in science. No one who wants to build up for himself a really justifiable opinion on this conflict can afford to leave the book unread.

Prof. de Santillana is a man of remarkable erudition, not only in the field of science and its history, but also in those of general history, literature, art and philosophy. With all these attainments merged into a general culture, one need not wonder that they appear in his writings again and again in the form of reminiscences and allusions which enhance the attractiveness of the story. However, I am sometimes afraid that the author tends to over-rate the intellectual capacities of the average reader.

The same remark applies to the numerous comparisons between certain aspects of Galileo's case and analogous situations in our own time. There are several allusions to contemporary American issues which the foreign reader may not always be able to appreciate. In so far as he is able to do so, however, he will admire the author's broad point of view, which allows him to present the process against Galileo as a particular case of a perennial conflict of scientific endeavour and social authority.

E. J. DiJKsterhors 